\title{
ÖRGÜTSEL ÖĞRENME YETENEĞININN GÖREV VE BAĞLAMSAL PERFORMANSA ETKİSİ: SAĞLIK SEKTÖRÜNDE BİR UYGULAMA
}

\begin{tabular}{|c|c|}
\hline $\begin{array}{r}\text { THE EFFECT OF ORC } \\
\text { CONTEXTUAL PERFOF }\end{array}$ & $\begin{array}{l}\text { NING CAPACITY ON TA } \\
\text { ATION IN THE HEALTH } \\
\text { RDOĞ A N"* }\end{array}$ \\
\hline $\begin{array}{l}\text { Geliş Tarihi: } 21.10 .2018 \\
\text { (Received) }\end{array}$ & $\begin{array}{l}\text { Kabul Tarihi: } 26.11 .2019 \\
\text { (Accepted) }\end{array}$ \\
\hline
\end{tabular}

ÖZ: Örgütsel öğrenme yeteneği kavramı, işletmelerin içerisinde hatayı bulma ve düzeltme, işletme içi rutinleri yürütme, bulunan veya görülen problemleri düzeltme, bilgi ve fikir çeşitliliği oluşturma, devamlı iyiye doğru yenilenmeyi amaçlamaktadır. İşletmelerin performansına etki eden, dolayısıyla karlılığının artmasında, markalaşmasında ve sürdürülebilirliğinde büyük pay sahibi olan örgütsel öğrenme yeteneği ve bu kavramı oluşturan alt boyutları derinlemesine incelenmiş olup edinilen literatür taraması ile şimdiye değin bu konuda araştırma yapan akademisyenler ve meydana getirdikleri modeller incelenmiştir. Bu safhada başkaca ele alınan bir diğer kavram olan öğrenen örgüt ile ilişkisi ve farkları ele alınmıştır. Örgütsel öğrenme ve örgütsel öğrenme yeteneği ülkemizde yeni bir kavram olarak karşımıza çıkmış olup önemi henüz kavranamamış bir konudur. Bu çalışmada; örgütsel öğrenme yeteneğinin görev ve bağlamsal performansa etkisi incelenmiştir. Araştırma kapsamında hazırlanan anket İstanbul ili Avrupa Yakasında faaliyet gösteren özel hastaneler içinden, araştırmaya katılmayı kabul eden hastanelerde çalışan 550 kişiye anket dağıtılmış olup 525 kişiden geri dönüş sağlanmıştır. Anket sonuçları SPSS ve AMOS programları yardımıyla kodlanmış ve analize tabi tutulmuşlardır. Sonuç olarak; örgütsel öğrenme kapasitesi alt boyutları ile birlikte iş performansı ve alt boyutlarını pozitif olarak etkilediği görülmüştür.

Anahtar Kelimeler: Örgütsel Öğrenme Kapasitesi, Öğrenen Örgüt, İş Performans1, Görev Performans1, Bağlamsal Performans.

ABSTRACT: Organizational learning ability is defined as a series and a set of organizational tasks and skills that authorize the organization to use its knowledge and experience based on the experience and knowledge gained, and to use this information as it grows and when knowledge is needed. The concept of organizational learning ability aims to find and correct mistakes in enterprises, to execute in-house routines, to fix problems that are found or seen, to create information and idea diversity, to be renewed continuously. The organizational learning ability and the sub-dimensions that affect the performance of the enterprises, which have a big share in profitability, branding and sustainability, have been

\footnotetext{
*Dr., Milli Savunma Üniversitesi, skeceli@hho.edu.tr, ORCID:0000-0001-7515-0757.

** Doç.Dr., Trakya Üniversitesi, alierdogan1975@gmail.com, ORCID:0000-0001-84035427.
} 
examined in depth and the literature that has been acquired has been investigated by the academicians who research in this issue and the models they have introduced. In this phase, the relation and the differences with the learning organization which is another concept which is discussed further are discussed. The ability of organizational learning and organizational learning has emerged as a new concept in our country and the issue has not yet been recognized. In this study; the effect of organizational learning capacity on task and contextual performance has been examined. Within the scope of the survey, the questionnaire was distributed to 550 people who work in the hospitals that accept to participate in the survey among the private hospitals operating in the Istanbul province of Europe and 525 people were returned. The survey results were coded and analyzed with the help of SPSS and AMOS programs. As a result; Organizational learning capacity, together with its sub-dimensions, was found to positively affect job performance and subdimensions.

Key Words: Organizational Learning Capacity, Learning Organization, Job Performance, Task Performance, Contextual Performance.

\section{GIRISS}

Mevcudiyetin devam1, gelirlerin giderlerden daha fazla olmasi olarak adlandırılan kârlılık ve diğer işletmelerle olan rekabetin sürdürülebilirliği şeklinde öğretilen işletmelerin temel amaçları, küreselleşen dünyamızda modern yönetim anlayışına geçildiği dönemden itibaren her sektörde hep ön planda tutulmaktadır. Sürekli iyileşme anlayışı ile de bu amaçlar pekiştirilmeye çalışılmaktadır. $\mathrm{Bu}$ safhada performans kavramı öne çıkmaktadır. İşletme yönetimi almış olduğu veya alacağ yapagelmektedirler. Örgütsel öğrenme, öğrenen örgüt ve örgütsel öğrenme kapasitesi ise performans kavramının pozitif etkenlerinden biri olarak karşımıza çıkmaktadır.

Performans denince akla ilk olarak bireysel anlamda çalışanlar gelmektedir. Araştırmacılar ister uluslararası isterse ulusal bazda, her ne kadar psikolojinin ve örgütsel davranışın çalışma sahası olsa da çalışan performansının artırılmasının davranışsal olarak incelenmesi üzerine yoğunlaşmaktadırlar. Her insanın olayları algılamaları ve verdikleri tepkiler birbirlerinden çok farklı olarak gerçekleşmektedir. Çalış1lan anakütle de hizmet sektörünün merkezinde olan hastanelerde çalışanların davranışlarının tespit edilerek performanslarının artırılmaları işletmenin hem hizmet kalitesi hem de hasta güvenliği bağlamında büyük öneme haizdir. Yapılacak olan tespitler, yönetim kademesine karar verme istikametinde yarar sağlayacağı, paralelinde işletmenin kârının artırılması, rekabet üstünlügünün var olması ve işletme mevcudiyetinin devamı bağlamında pozitif katkıları olacağı düşünülmektedir.

$\mathrm{Bu}$ çalışmanın ikinci bölümünde örgütsel öğrenme, öğrenen örgüt ve örgütsel öğrenme yeteneği hakkında açıklayıcı bilgiler sunulmaktadır. Çalışmanın 
üçüncü bölümünde; performans kavramı ve performans çeşitlerinden biri olan iş performansı derinlemesine incelenmiş olup örgütsel davranış yaklaşımı açısından iş performansı türleri ve diğer performans türleri konuları ele alınmıştır. Çalışmanın dördüncü bölümünde örgütsel öğrenme ve performans arasında daha önceden yapılmış olan çalışmalar literatürel olarak ele alınmış olup, ülkemizde ve ülke dışında şeklinde kategorize edilerek bu bölümde yer verilmiştir. Araştırmanın beşinci bölümünde ise araştırma ve uygulamaya yönelik bilgiler verilmiştir. Araştırma İstanbul ili avrupa yakasında hizmet veren on (10) adet sağlık kuruluşu üzerinde yapılmıştır.

\section{LITERATÜR}

Örgütsel öğrenme, organizasyonların öğrenme sürecidir. Öğrenme, performansı koruyan ya da geliştiren örgütsel modellemelerde yapılan herhangi bir değişikliğidir (DiBella ve diğ., 1996). Örgütsel öğrenme kabiliyeti; işletmenin yeni rekabet avantajı biçimleri elde etmek için kullandığı maddi ve manevi kaynaklar veya beceriler demetidir. $\mathrm{Bu}$ beceriler organizasyonel öğrenme sürecini etkinleştirir. Öök, genellikle örgütsel öğrenmeyle ilgili ön şartları öne süren literatürle ilişkilidir (Hult ve ark, 1997; Jérez-Gómez ve diğ., 2005). Bazı ön koşulların yerine getirilmesi halinde öğrenmenin teşvik edilebileceği ve yönlendirilebileceğine işaret edilmektedir. Bir organizasyonun yenilik yaratma etkinliğinin ve potansiyelinin anahtar göstergesi öğrenme kapasitesidir (JérezGómez ve diğ., 2005).

Öğrenen örgütlere dönüşmesi hedeflenilen hastanelerde sağl1k emekçilerinin örgütsel öğrenme ile inovasyon başlıkları hakkındaki görüşleri, düşünceleri ve konulara bakışları çok ehemmiyetlidir. Örnek olarak, Erigüç ve Balçık tarafından 2007 yılında yapılan araştırma neticeleri incelendiğinde, sağlık çalışanlarının yapitaşı olan hemşirelerin bireysel seviyede, grup seviyesinde ve örgütsel bazda örgütsel öğrenme boyutlarına dair değerlendirmelerinin çok düşük seviyede var olduğu tespit edilmiştir. Girgin'in 2015 y1lında yapmış olduğu hastane çalışanlarına dair araştırmada;değişik boyutları ile ele alınan öğrenme yenileşim süreçleri içerisinde kendine yer bulan gerek duyulan ve önemli bir girdi şeklinde değerlendirilebilir olup performans üzerinde de ehemmiyetli etkiye sahip bulunduğu tespit edilmiştir. Öğrenme ve performans konularını makro çerçeveden ele almanın yanında iki kavramın birlikte incelenmesi gerekliliği özellikle aracı değişken olarak ilişkisinide içine alacak şekilde kurumsal performans ve finansal performans, pazarlama bilgi sistemi içsel dişsal motivasyon, girişimcilik ve kurumsal imaj v.b. konular ile de ilişkilendirmelerde bulunulan çok sayıda araştırma yapıldığı gözlemlenmektedir (Avcı, 2009; Baker ve Sinkula, 1999; Girgin, 2015; Çelik, 2009). Aksay ve diğ., (2016: 114-129) tarafindan anakütle 
olarak seçilen eğitim araştırma hastanesinde incelenen araştırma neticelerine bakıldığında, bilginin edinilen deneyime dayalı, yenilikçilik potansiyelinin tespit edicilerinden olduğu neticesine varılmıştır. Cezlan'ın 2014 yılında İstanbul'da hizmet sunan sağlık kuruluşları üzerine yaptığı araştırma neticesinde ise; işletme yenilikçiliği ve örgütsel sermayenin işletme performansına pozitif yönlü katkı sağladığı sonucuna varılmıştır. Bu neticeler entelektüel sermayenin işletme performansı ve işletme yenilikçiliği ile korelasyonunu ve yenilikçiliğin performans üzerindeki etkisini ve önemini belirtmektedir. Kaynağı insan olan sermayenin öğrenme ve çalışanın etkili liderlik doğrulumu vasıtasıyla işletme performansına etkisi bulunmaktadır.

Horuz 2016 y1lında bir sağlık kuruluşunda "360 derece performans değerlendirme sisteminin örgütsel öğrenme kapasitesi üzerine etkisi” başlıklı araştırmaya imza atmıştır. Bu sebeple bir bakıma örgütlerin örgütsel öğrenme kapasitesi ile 360 derece performans değerlendirme sistemi ikilisinde ilişki içinde olduğu hipotezine varılmaktadır. Elde edilen diğer bir netice ise hekimlerin haricindeki sağlık çalışanlarının performans değerlendirme üzerine bir bilgiye vakıf olmamalarıdır.

Efe ve Sevinç (2018)'in yapmış oldukları araştırma sonucunda da örgütsel öğrenme yeteneğinin firma performansını pozitif yönde etkilediği yönünde sonuç elde etmişlerdir.

Şimdiye değin verilen veriler ve yapılan araştırmalar neticesinde özellikle sağlık çalışanları bağlamında öğrenme ve performans ilişkisi ve etkisi üzerinde çalışmaların yoğunlaşılması ve bu hususdaki farkındalığın artırılması büyük önem arz etmektedir.

\section{ARAȘTIRMA}

Bu bölümde araştırmanın amacı, evren ve örneklemi, metodoloji, modeli, değişkenleri, hipotezleri, ölçekleri iel analiz ve bulgularına yer verilecektir.

\subsection{Amaç}

Araştırmanın amac1; örgütsel öğrenme yeteneğinin algılanan iş performansına etkisinin analizinde her iki değişken bağlamında alt boyutlarının hangisinin ne derece etkilerinin bulunduğunu detaylı bir şekilde araştırarak ve nihayetinde bulunan veriler 1şı̆̆ında işletme yönetimine ve çalışanlarına organizasyonel ve yönetimsel önerilerde bulunulması amaçlanmaktır. Ana kütle bağlamında İstanbul ili Avrupa yakası özel hastanelerin örgütsel öğrenme yeteneklerinin olup olmadığının tespit edilmesi ve deneyim, risk alma, dış çevre ile etkileşim, diyalog ve katılımcı karar verme alt boyutlarının hangilerinin ne oranda var olduklarının bilinmesi öncelikli amaçlardandır. Daha sonra kurum çalışanlarının sahip oldukları örgütsel öğrenme yeteneğinin algıladıkları 
performansları üzerinde etkilerinin araştırılarak tespit edilip analizlere tabi tutulmaları diğer temel amaç olarak karşımıza çıkmaktadır.

\section{2.}

\section{Evren ve Örneklem}

Araştırmanın evrenini İstanbul İli Avrupa yakasında hizmet veren 10 (on) adet özel hastane çalışanları oluşturmaktadır. Araştırmanın ana kütlesi fazla olduğu, kişilere ulaşma zorluğu çekildiği, maddi açıdan zorluklar doğuracağ 1 , zaman açısından uzun süreler ihtiyaç duyulacağı için örneklem metodu ile araştırma devam ettirilmiştir. Her bir hastane çalışanının eşit şansa sahip olduğu düşüncesi ile örneklem metodu olarak basit tesadüfi örneklem kullanılmıştır. Sebebi ise araştırmacı tarafindan örgütsel öğrenme ve performans değişkenlerinin her ikisinde de ankete katılım sağlayan çalışanların aralarında bir fark olmadığ örnekleme girme şanslarının aynı olduğu düşünülerek bu örnekleme yöntemi seçilmiştir. Bu metot kullanılırken ana kütleyi oluşturan bütün çalışanların her birerlerinden örneklemde yer verilmiştir. Nihayetinde 550 adet anket verilmiştir. 525 tanesi kabul edilmiştir.

\subsection{Metodoloji}

Araştırmanın bu safhasında; öncelikle araştırmanın değişkenleri ve ölçekleri, araştırmaya dair oluşturulan modeli, evren hakkında bilgiler sunma adına alınan örnekleme süreci, araştırmanın sorunsallarına dair varsayımları ve bilgi elde edilme yöntemine dair verilere yer verilmektedir.

\subsection{Araştırmanın Modeli}

Şekil 1' de araştırmanın modeli gösterilmektedir.

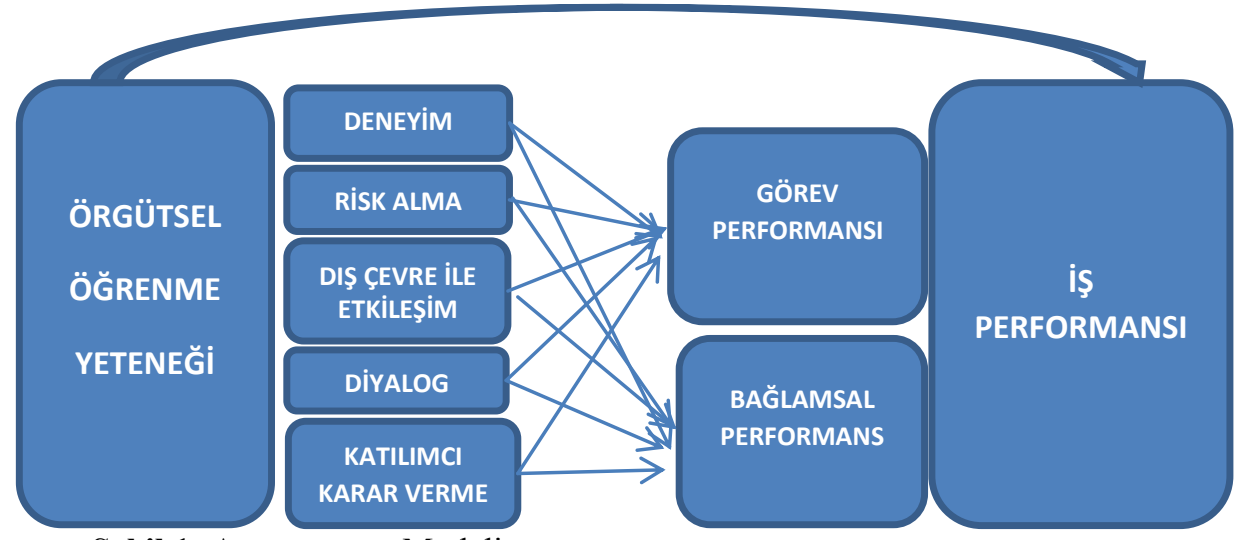

Şekil 1: Araştırmanın Modeli 


\subsection{Değişkenler}

Araştırmanın bağımsız değişkeni örgütsel öğrenme yeteneğinin alt boyutlarından olan deneyim, risk alma, dış çevre ile etkileşim, diyalog ve son olarak katılımcı karar verme değişkenlerinden meydana gelmektedir. Yapılan araştırmanın bağımlı değişkeni ise iş performansının alt boyutlarından görev performansı ve bağlamsal performanslarıdır.

\subsection{Hipotezler}

Araştırma onbir adet hipotezden oluşturulmuştur. Bu hipotezler Tablo 1'de tablolaştırılmıştır.

Tablo 1: Araştırmanın Hipotezleri

\section{Hipotezler}

$\mathrm{H}_{1} \quad$ Örgütsel öğrenme kapasitesinin deneyim alt boyutunun iş performansı alt

$H_{1}$ boyutu olan bağlamsal performans üzerine anlamlı bir etkisi bulunmaktadır.

$\mathrm{H}_{2} \quad$ Örgütsel öğrenme kapasitesinin deneyim alt boyutunun iş performans1 alt

$\mathrm{H}_{2}$ boyutu olan görev performansı üzerine anlamlı bir etkisi bulunmaktadır.

$\mathrm{H}_{3} \quad$ Örgütsel öğrenme kapasitesinin risk alma alt boyutunun iş performansı alt

$\mathrm{H}_{3}$ boyutu olan bağlamsal performans üzerine anlamlı bir etkisi bulunmaktadır.

$\mathrm{H}_{4} \quad$ Örgütsel öğrenme kapasitesinin risk alma alt boyutunun iş performansı alt

$\mathrm{H}_{4}$ boyutu olan görev performansı üzerine anlamlı bir etkisi bulunmaktadır.

Örgütsel öğrenme kapasitesinin dış çevre ile etkileşim alt boyutunun iş

$\mathrm{H}_{5}$ performansı alt boyutu olan bağlamsal performans üzerine anlamlı bir etkisi bulunmaktadır.

Örgütsel öğrenme kapasitesinin dış çevre ile etkileşim alt boyutunun iş

$\mathrm{H}_{6} \quad$ performansı alt boyutu olan görev performansı üzerine anlamlı bir etkisi bulunmaktadır.

$\mathrm{H}_{7} \quad$ Örgütsel öğrenme kapasitesinin diyalog alt boyutunun iş performansı alt

$\mathrm{H}_{7}$ boyutu olan bağlamsal performans üzerine anlamlı bir etkisi bulunmaktadır.

$\mathrm{H}_{8} \quad$ Örgütsel öğrenme kapasitesinin diyalog alt boyutunun iş performansı alt boyutu olan görev performansı üzerine anlamlı bir etkisi bulunmaktadır.

Örgütsel öğrenme kapasitesinin katılımcı karar alma alt boyutunun iş

$\mathrm{H}_{9} \quad$ performansı alt boyutu olan bağlamsal performans üzerine anlamlı bir etkisi bulunmaktadır.

Örgütsel öğrenme kapasitesinin katılımcı karar alma alt boyutunun iş

$\mathrm{H}_{10}$ performansı alt boyutu olan görev performansı üzerine anlamlı bir etkisi bulunmaktadır.

$\mathrm{H}_{11} \quad$ Örgütsel öğrenme kapasitesi değişkeninin iş performansı değişkeni üzerine anlamlı bir etkisi bulunmaktadır.

Tablo 1'de gösterildiği gibi 11 tane hipotezimiz mevcut. Araştırmanın sonuç bölümünde hipotez sonuçlarına ilişkin verilere yer verilecektir. 
DOI: $10.26468 /$ trakyasobed.486447

\section{7. Ölçekler}

Ricardo CHIVA tarafından geliştirilen ve 14 sorudan oluşan örgütsel öğrenme ölçeği bulunmaktadır. Ölçek, Aydoğan ve arkadaşları (2011) tarafından da yapılmış olan araştırmada güvenilirlik katsayısı 0,93 olarak yüksek güvenilirlikte bulunmuştur.

Görev ve bağlamsal performansı ölçmek üzere Smith, Organ ve Near tarafindan (1983) geliştirilen 16 maddeli ankete, Goodman ve Svyantek'in (1999: 254-275) 9 adet görev performansı maddelerinin eklenmesi ile oluşan ölçeğin türkçeye çevrilmiş ve sadeleştirilmiş şekli kullanılmıştır.

\subsection{Analiz ve Bulgular}

Araştırmanın analizine ait yol haritasını şu şekilde sıralayabiliriz: Demografik veriler, analiz öncesi tanımlayıcı istatistikler, geçerlik ve güvenirlik analizleri, faktör analizi (kmo-barlett), doğrulayıcı faktör analizi (dfa), dfa sonrası güvenirlik analizi, katılımcıların sosyo-demografik özellikleri bağlamında farkları, değişkenler arası ilişki (korelasyon), değişkenler arası etki (regresyon).

Demografik Veriler: Çalışanların; \%61,9'u kadın, \%37,9'u erkek; \%29,7 ile çoğunluğu 41-50 yaş arasında; öğrenim olarak \%35,4 ile çoğunluğu lisans mezunu; \%46,7 ile çoğunluğu haftalık çalışma saati 41-50 saat arası; \%49 ile çoğunluğu hemşire mesleğine sahip; \%40,6 ile çoğunluğu 3001-4000 tl. aylık maaş alan; hastanedeki hizmet süreleri açısından $\% 38,1$ ile çoğunluğu 5 yıl ve aşağısı çalışanlar; \%35,4 ile çoğunluğu cerrahi branşlarda çalışanlardan oluşturmaktadır.

Analiz Öncesi Tanımlayıcı İstatistik: Maddelerin çarpıklık değerleri -1,049 ile -,160 arasında, maddelerin basıklık değerleri ise 2,933 ile -,016 arasında değişkenlik gösterdiğinden, çok değişkenli normallik niteliği şartlarına haiz bulunduğundan söz edebiliriz. Bunlara dair verilerle ilgili Erdoğan'a göre, Çarpıklık ve basıklık değerlerinin -3 ile +3 arasında $(-3<\mathrm{p}<+3)$ olması normal değerler arasında olduğunu göstermektedir (Erdoğan, 2015: 73). İlaveten shapirowilk-w testi normallik varsayımını sınayan en güçlü test olarak karşımıza çıkmaktadır. Normallik sınaması için kullanılan Shapiro Wilk test istatistiği 0,839 olarak bulunmuştur. Bu paralelde verilerimizin normal dağılmakta olduğundan söz edebiliriz.

Geçerlik Güvenirlik Analizleri: Ankete katılım sağlayan tarafindan verilen cevaplar Cronbach Alpha güvenilirlik testine tabi tutulmuş. Netice olarak örgütsel öğrenme kapasitesi değeri 0,938 ; alt boyutlarından olan deneyim değeri 0,850 , risk alma 0,749 , dış çevre ile etkileşim 0,792 , diyalog 0,825 ve son olarak katılımcı karar verme 0.891 değeri bulunmuştur. İş performansı ölçeği güvenirlik testinde ise iş performansı değeri 0,916; alt boyutları olan bağlamsal performans değeri 0,850 ve görev performansı değeri 0,889 olarak bulunmuştur. Her iki değişkenin ortalama 
Cronbach Alpha değeri ise 0,927 olarak bulunmuştur. Bu neticelere göre araştırma ölçeğinin Cronbach Alpha güvenirlik sonucu "yüksek derecede güvenilir ölçek" olduğu söylenebilmektedir.

Faktör Analizi (kmo-barlett): Her iki ölçeğin kmo katsayısı 0,933'dür. Örgütsel öğrenme kapasitesi kmo katsayısı 0,941'dir. İş performansı kmo katsayısı 0,928 'dir. Bu neticelere göre örneklemimizin boyutunun faktör analizine uygun halde olduğu sonucuna varılmaktadır. Aynı şekilde genel faktör bartlett sınaması değeri=11122,441; $p=0,000$ şeklinde; örgütsel öğrenme kapasitesi bartlett sinamas değeri $=4987,429 ; \quad \mathrm{p}=0,000$ şeklinde; iş performans1 bartlett sinamas değeri $=5596,551 ; p=0,000$ şeklinde sonuca sahip olunmuştur. Bu sonuçlar 0,05 anlamlılık seviyesinden küçük olduğundan dolayı Bartlett Analiz neticesi anlamlıdır. En son olarak bu değerlerden yola çıkarak verilerin faktör analizine uygun halde olduğu söylenmektedir ve faktör analizi yapılabilir olarak değerlendirilmektedir.

Doğrulayıcı Faktör Analizi (DFA):

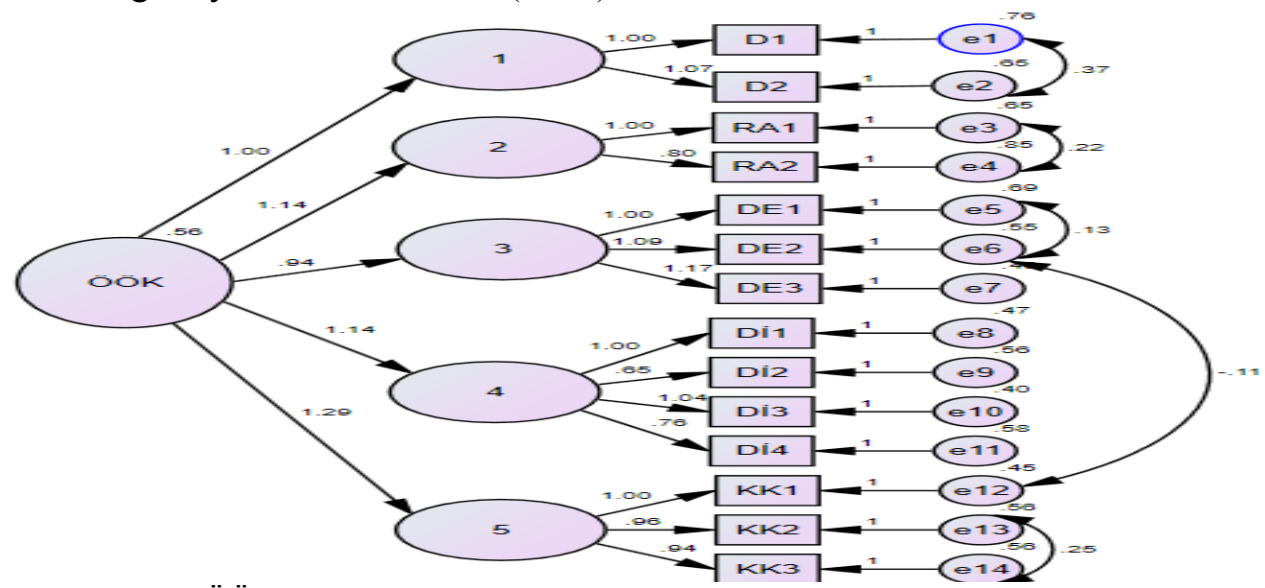

Şekil 2: ÖÖK'si 2. Düzey Doğrulayıcı Faktör Analizi Modeli

*1=deneyim, $2=$ risk alma $3=$ dış çevre ile etkileşim, 4=diyalog, 5=katılımcı karar verme

Örgütsel öğrenme Kapasitesi ikinci düzey doğrulayıcı faktör analizine yer verilmiştir. Şekil 2' de gösterildiğgi gibi oluşturulmuştur.

Tablo 2: ÖÖK. Ölçeğinin Doğrulayıcı Faktör Analizi Neticeleri

\begin{tabular}{|c|c|c|c|c|}
\hline $\begin{array}{c}\text { Uyum } \\
\text { Ölçüleri }\end{array}$ & İyi Uyum & Kabul Edilebilir Uyum & $\begin{array}{c}\text { Hesaplanan } \\
\text { Değer }\end{array}$ & Uyum Durumu \\
\hline$\chi^{2}$ & & & 297,656 & \\
\hline Df (p) & & & 72 & \\
\hline$\chi^{2} / \mathbf{d f}$ & $\leq 3$ & $\leq 4-5$ & 4,134 & $\begin{array}{l}\text { Kabul edilebilir } \\
\text { uyum }\end{array}$ \\
\hline
\end{tabular}


Trakya Üniversitesi Sosyal Bilimler Dergisi

Aralık 2019 Cilt 21 Sayı 2 (491-510)

DOI: $10.26468 /$ trakyasobed.486447

\begin{tabular}{|c|c|c|c|c|}
\hline RMSEA & $0<$ RMSEA $<0,05$ & $0,05 \leq$ RMSEA $\leq 0,08$ & 0,077 & $\begin{array}{l}\text { Kabul edilebilir } \\
\text { uyum }\end{array}$ \\
\hline NFI & $0,95 \leq \mathrm{NFI} \leq 1$ & $0,90 \leq \mathrm{NFI}<0,95$ & 0,937 & $\begin{array}{l}\text { Kabul edilebilir } \\
\text { uyum }\end{array}$ \\
\hline NNFI & $0,95 \leq \mathrm{NNFI} \leq 1$ & $0,90 \leq \mathrm{NNFI}<0,95$ & 0,939 & $\begin{array}{l}\text { Kabul edilebilir } \\
\text { uyum }\end{array}$ \\
\hline CFI & $0,97 \leq \mathrm{CFI} \leq 1$ & $0,95 \leq \mathrm{CFI}<0,97$ & 0,951 & $\begin{array}{l}\text { Kabul edilebilir } \\
\text { uyum }\end{array}$ \\
\hline IFI & $0,95 \leq \mathrm{IFI} \leq 1$ & $0,90 \leq \mathrm{IFI}<0,95$ & 0,952 & İyi uyum \\
\hline GFI & $0,90 \leq \mathrm{GFI} \leq 1$ & $0,85 \leq \mathrm{GFI}<0,90$ & 0,924 & İyi uyum \\
\hline
\end{tabular}

Kaynak: Meydan, C.H. ve Seșen, H. (2015) Yapısal Eșitlik Modellemesi AMOS Uygulamaları (2. Baskı), Ankara: Detay Yayıncılık.

İş performansı Ölçeği Doğrulayıcı Faktör analizi:

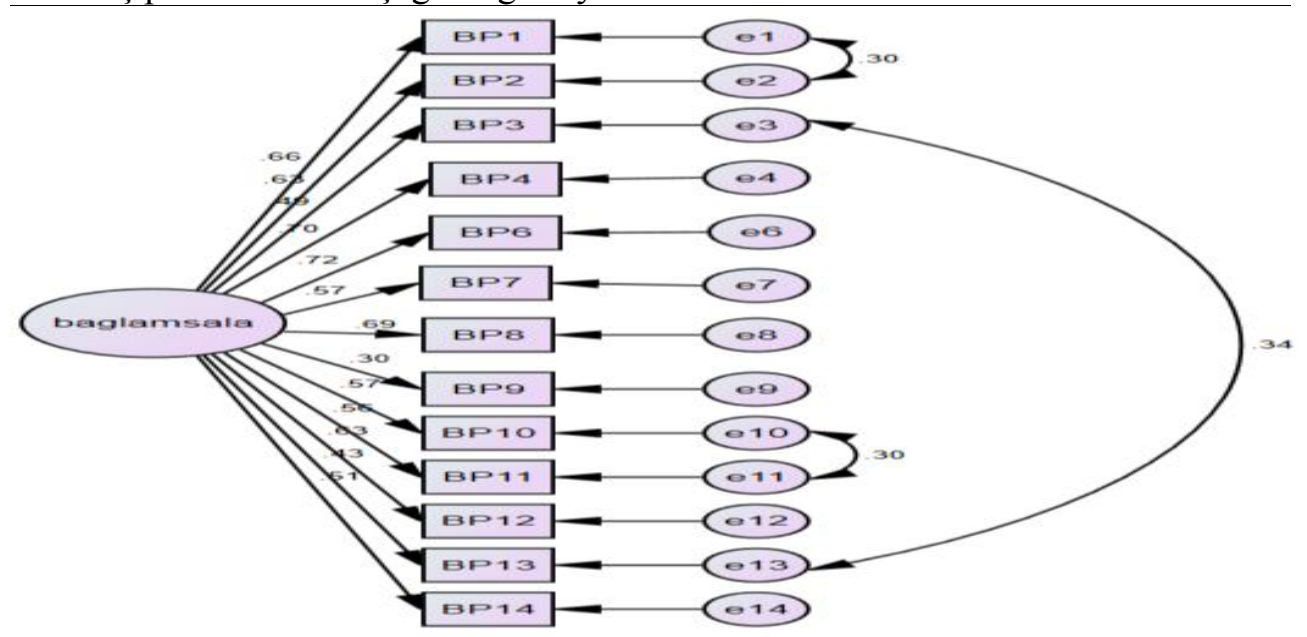

Şekil 3: Bağlamsal Perf. Ölç. Tek Boyutlu Doğrulayıcı Faktör Analizi Modeli

İş performansı alt boyutlarından bağlamsal performansına ait doğrulayıcı faktör analizine yer verilmiştir.

Tablo 3: Bağlamsal Performans Ölçeğinin Doğrulayıcı Faktör Sonuçları

\begin{tabular}{ccccl}
\hline $\begin{array}{c}\text { Uyum } \\
\text { Ölçüleri }\end{array}$ & İyi Uyum & $\begin{array}{c}\text { Kabul Edilebilir } \\
\text { Uyum }\end{array}$ & $\begin{array}{c}\text { Hesaplanan } \\
\text { Değer }\end{array}$ & Uyum Durumu \\
\hline$\chi^{2}$ & & & 190,870 & \\
Df $(\mathbf{p})$ & & $\leq 4-5$ & 62 & \\
$\chi^{2} / \mathbf{d f}$ & $\leq 3$ & 3,079 & İyi uyum \\
RMSEA & $0<\mathrm{RMSEA}<0,05$ & $0,05 \leq \mathrm{RMSEA} \leq 0,08$ & 0,063 & Kabul edilebilir uyum \\
NFI & $0,95 \leq \mathrm{NFI} \leq 1$ & $0,90 \leq \mathrm{NFI}<0,95$ & 0,916 & Kabul edilebilir uyum \\
NNFI & $0,95 \leq \mathrm{NNFI} \leq 1$ & $0,90 \leq \mathrm{NNFI}<0,95$ & 0,926 & Kabul edilebilir uyum \\
CFI & $0,97 \leq \mathrm{CFI} \leq 1$ & $0,94 \leq \mathrm{CFI}<0,97$ & 0,941 & Kabul edilebilir uyum
\end{tabular}




$\begin{array}{ccccl}\text { IFI } & 0,95 \leq \text { IFI } \leq 1 & 0,90 \leq \text { IFI }<0,95 & 0,941 & \text { Kabul edilebilir uyum } \\ \text { GFI } & 0,90 \leq \text { GFI } \leq 1 & 0,85 \leq \text { GFI }<0,90 & 0,945 & \text { İyi uyum }\end{array}$

Kaynak: Meydan, C.H. ve Şeşen, H. (2015) Yapısal Eşitlik Modellemesi AMOS Uygulamaları (2. Baskl), Ankara: Detay Yayıncılık.

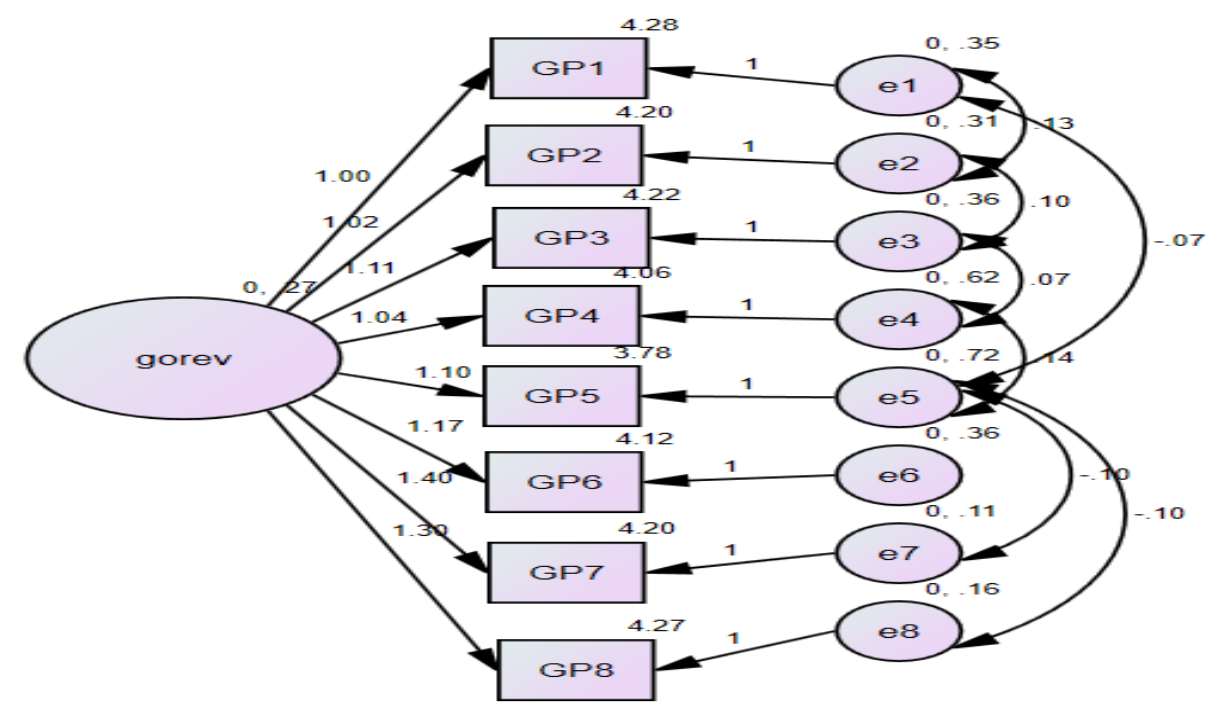

Şekil 4: Görev Perf. Boyutu için Tek Boyutlu Doğrulayıcı Faktör Analizi Modeli

Şekil 4' te iş performansı alt boyutlarından görev performansına ait doğrulayıcı faktör analizine yer verilmiştir.

Tablo 4: Görev Performansı Ölçeğinin Doğrulayıcı Faktör Sonuçları

\begin{tabular}{ccccl}
\hline $\begin{array}{c}\text { Uyum } \\
\text { Ölçüleri }\end{array}$ & İyi Uyum & $\begin{array}{c}\text { Kabul Edilebilir } \\
\text { Uyum }\end{array}$ & $\begin{array}{c}\text { Hesaplanan } \\
\text { Değer }\end{array}$ & Uyum Durumu \\
\hline$\chi^{2}$ & & & 54,762 & \\
Df $(\mathbf{p})$ & $\leq 3$ & 13 & \\
$\chi^{2} / \mathbf{d f}$ & & $\leq 4-5$ & 4,212 & Kabul edilebilir uyum \\
RMSEA & $0<\mathrm{RMSEA}<0,05$ & $0,05 \leq \mathrm{RMSEA} \leq 0,08$ & 0,078 & Kabul edilebilir uyum \\
NFI & $0,95 \leq \mathrm{NFI} \leq 1$ & $0,90 \leq \mathrm{NFI}<0,95$ & 0,976 & İyi uyum \\
NNFI & $0,95 \leq \mathrm{NNFI} \leq 1$ & $0,90 \leq \mathrm{NNFI}<0,95$ & 0,949 & Kabul edilebilir uyum \\
CFI & $0,97 \leq \mathrm{CFI} \leq 1$ & $0,95 \leq \mathrm{CFI}<0,97$ & 0,982 & İyi uyum \\
IFI & $0,95 \leq \mathrm{IFI} \leq 1$ & $0,90 \leq \mathrm{IFI} \leq 0,95$ & 0,982 & İyi uyum \\
GFI & $0,90 \leq \mathrm{GFI} \leq 1$ & $0,85 \leq \mathrm{GFI} \leq 0,90$ & 0,954 & İyi uyum \\
\hline
\end{tabular}

Kaynak: Meydan, C.H. ve Şeşen, H. (2015) Yapısal Eşitlik Modellemesi AMOS Uygulamaları, 2. Baskı, Detay Yayıncılık, Ankara 2015. 
DOI: $10.26468 /$ trakyasobed.486447

Doğrulayıcı Faktör Analizi Sonrası Güvenirlilik Analizleri: Öök. ölçeği 0,938 ; deneyim 0,850 ; risk alma 0,749 ; diş çevre ile etkileşim 0,792 ; diyalog 0,825 ; katılımcı karar verme 0,891 ; iş performansı ölçeği 0,922 ; bağlamsal performans 0,861 ; görev performans1 0,889 son olarak genel Cronbach's alfa değeri 0,919 olarak bulunmuştur.

Katılımcıların Örgütsel Öğrenme Kapasitesi Puanlarının SosyoDemografik Özelliklerine Göre Farklılıkları: Katılımcıların Öök ve alt boyutlarının cinsiyete göre $t$ testi sonuçlarında sadece risk alma alt boyutunda $(0,027 \mathrm{p}$ değeri) ile bir farklılık görülmüştür. İş performansında bir farklılık görülmemiştir.

Katılımcıların öök ve alt boyutlarının haftalık çalışma saatine göre ortalama, standart sapma ve tek faktörlü anova sonuçlarında katılımcı karar verme hariç diğer boyutlarda 40 saat ve altı ile 41-50 saat arasinda ve 40 saat ve altı ile 51 saat ve üstü arasında farklılık vardır. Katılımcı karar verme boyutunda ise diğerlerine ek olarak 40 saat altı ile 51 saat ve üstü arasında farklılık vardır. İş performansı değişkeninde ise bağlamsal ve iş performansı boyutlarında 40 saat ve altı ile 51 saat ve üstü arasında farkl11ık vardır. Görev performansı boyutunda fark yoktur.

Çalışanların örgütsel öğrenme kapasitesi ve alt boyutlarının yaşa göre ortalama, standart sapma ve tek faktörlü anova sonuçlarında sadece dış çevre ile etkileşim boyutunda farklılık vardır, diğerlerinde yoktur. İş performansı değişkeninde ise farklılık yoktur.

Örgütsel öğrenme kapasitesi ve alt boyutlarının öğrenim durumuna göre ortalama, standart sapma ve tek faktörlü anova sonuçlarında deneyim boyutunda yok; risk alma, diyalog ve öök. boyutlarında yüksek lisans ile doktora arasında farklılık vardır. Katılımcı karar vermede ise ek olarak önlisans ile lisans arasında farklılık vardır. İş performansı değişkeninde fark yoktur.

Örgütsel öğrenme kapasitesi ve alt boyutlarının mesleklerine göre ortalama, standart sapma ve tek faktörlü anova sonuçlarında deneyimde doktorlar ile diğer personel arasında; risk alma ve katılımcı karar verme boyutlarında hemşire-sağlık memuru, sağlık memuru-tekniker/teknisyen ve sağlı memuru-diğer personel arasında; diyalog ve öök. boyutlarında ise sadece sağlık memuru ile diğer personel arasında farlılık bulunmuştur. Dış çevre ile etkileşim boyutunda fark yoktur. Yine iş performansı değişkeninde fark görülmemiştir.

Örgütsel öğrenme kapasitesi ve alt boyutlarının aylık gelirlerine göre ortalama, standart sapma ve tek faktörlü anova Sonuçlarında her iki değişkende farklılık bulunmamıştır.

Örgütsel öğrenme kapasitesi ve alt boyutlarının hastane hizmet sürelerine göre deneyim boyutunda her varyans birbirleri farklılıkları vardır. Risk alma ve 
öök. boyutunda 5 yıl ve altı ile 11-15 yıl arasında; 6-10 yıl ile 11-15 yıl arasında; 11-15 yıl ile 16-20 yıl arasında farklılık vardır. Dış çevre ile etkileşim boyutunda 5 yıl ve altı ile 11-15 yıl arasında farklılık vardır. Katılıme karar verme ile 5 yıl ve alt1 ile 11-15 y1l arasinda; 6-10 ile 16-20 y1l arasinda fark var. Diyalog boyutunda ve iş performansı değişkeninde farklılıklar yoktur.

\subsection{1. Örgütsel Öğrenme Kapasitesi ve Alt Boyutları ile İş Performansı ve Alt Boyutları Arasındaki İlişki (Korelasyon) Analizi ve Yorumları}

Tablo 5' te örgütsel öğrenme kapasitesi ve alt boyutları ile iş performansı ve alt boyutları arasındaki ilişki (korelasyon) analizi ve yorumları sunulacaktır.

Tablo 5:ÖÖK. ve Alt Boyutları ile İş Performansı ve Alt Boyutları Arasındaki İlişki

\begin{tabular}{|c|c|c|c|c|c|c|c|c|c|c|}
\hline \multicolumn{2}{|c|}{$\begin{array}{l}\text { DEĞISSKENLER } \\
(\mathrm{n}=525)\end{array}$} & ÖÖK & Deneyim & $\begin{array}{l}\text { Risk } \\
\text { Alma }\end{array}$ & \begin{tabular}{|l|} 
Diş \\
Çevre \\
ile \\
Etki.
\end{tabular} & Diya. & $\begin{array}{l}\text { Katılım. } \\
\text { Karar } \\
\text { Verme }\end{array}$ & \begin{tabular}{|l|} 
İs \\
Perf.
\end{tabular} & $\begin{array}{l}\text { Bağlam. } \\
\text { Perf. }\end{array}$ & $\begin{array}{l}\text { Grv. } \\
\text { Perf. }\end{array}$ \\
\hline \begin{tabular}{l|} 
Örgütsel \\
Öğrenme \\
Kapasitesi \\
\end{tabular} & $\mathrm{r}$ & 1 & & & & & & & & \\
\hline \multirow{2}{*}{ Deneyim } & $\mathrm{r}$ &, $792^{* *}$ & \multirow{2}{*}{1} & & & & & & & \\
\hline & $\mathrm{p}$ & ,000 & & & & & & & & \\
\hline \multirow{2}{*}{ Risk Alma } & $\mathrm{r}$ &, $805^{* *}$ &, $627^{* *}$ & \multirow{2}{*}{1} & & & & & & \\
\hline & $\mathrm{p}$ & ,000 &, 000 & & & & & & & \\
\hline \multirow{2}{*}{$\begin{array}{l}\text { Dış Çevre } \\
\text { ile } \\
\text { Etkileşim }\end{array}$} & $\mathrm{r}$ &, $870^{* *}$ &, $601^{* *}$ &, $633^{* *}$ & \multirow{2}{*}{1} & & & & & \\
\hline & $\mathrm{p}$ &, 000 &, 000 &, 000 & & & & & & \\
\hline \multirow{2}{*}{ Diyalog } & $\mathrm{r}$ &, $892^{* *}$ &, $622^{* *}$ &, $596^{* *}$ &, $756^{* *}$ & \multirow{2}{*}{1} & & & & \\
\hline & $\mathrm{p}$ &, 000 &, 000 &, 000 &, 000 & & & & & \\
\hline \multirow{2}{*}{$\begin{array}{l}\text { Katılımeı } \\
\text { Karar } \\
\text { Verme }\end{array}$} & $\mathrm{r}$ &, $890^{* *}$ &, $626^{* *}$ &, $678^{* *}$ &, $690^{* *}$ &, $736^{* *}$ & \multirow[b]{2}{*}{1} & & & \\
\hline & $\mathrm{p}$ &, 000 &, 000 &, 000 &, 000 &, 000 & & & & \\
\hline \multirow{2}{*}{ İş Perf. } & $\mathrm{r}$ &, $394^{* *}$ &, $292^{* *}$ &, $268^{* *}$ &, $391^{* * *}$ &, $421^{* * *}$ &, $284^{* *}$ & \multirow{2}{*}{1} & & \\
\hline & $\mathrm{p}$ & ,000 &, 000 &, 000 &, 000 &, 000 & ,000 & & & \\
\hline $\begin{array}{l}\text { Bağlamsal } \\
\text { Perf. }\end{array}$ & $\mathrm{r}$ &, $377^{* *}$ &, $280^{* *}$ &, $254^{* *}$ &, $380^{* *}$ &, $402^{* *}$ &, $267^{* *}$ &, $960^{* *}$ & 1 & \\
\hline
\end{tabular}




\begin{tabular}{|l|l|l|l|l|l|l|l|l|l|l|}
\hline & $\mathrm{p}$ &, 000 &, 000 &, 000 &, 000 &, 000 &, 000 &, 000 & & \\
\hline \multirow{2}{*}{$\begin{array}{l}\text { Görev } \\
\text { Perfor. }\end{array}$} & $\mathrm{r}$ &, $362^{* *}$ &, $267^{* *}$ &, $249^{* *}$ &, $349^{* *}$ &, $387^{* *}$ &, $268^{* *}$ &, $912^{* *}$ &, $762^{* *}$ & \\
\cline { 2 - 10 } & $\mathrm{p}$ &, 000 &, 000 &, 000 &, 000 &, 000 &, 000 &, 000 &, 000 & 1 \\
\hline
\end{tabular}

Kısaltmaları verecek olursak; örgütsel öğrenme kapasitesi (öök), deneyim (de.), risk alma (ra), dış çevre ile etkileşim (dç), diyalog (di), katılımcı karar verme (kkv), iş performansı (ip), görev performans1 (gp), bağlamsal performans (bp). Bütün ilişkiler pozitif yönlü ve doğrusal ilişki olarak gerçekleşmiştir. Bu veriler doğrultusunda değişkenlerin korelasyon katsayısının gücü şu şekilde oluşmuştur; bp ile ra arasında çok zayıf ilişki vardır. gp ile öök; gp ile de; gp ile ra; gp ile dç; gp ile di; gp ile kkv; bp ile öök; bp ile de; bp ile dç; bp ile di; bp ile kkv; ip ile öök, de, ra, dç, di, kkv arasında zayıf iliş̧ki vardır. kkv ile de; kkv ile ra; kkv ile dç; di ile de; di ile ra; dç ile de; dç ile ra ve ra ile de arasında orta ilişki vardır. gp ile bp; kkv ile öök; kkv ile di; di ile öök; di ile dç; dç ile öök; ra ile öök ve de ile öök arasında yüksek ilişki vardır. Gp ile ip ve bp ile ip arasında çok yüksek ilişki vardır.

3.8.2. Araştırmanın Hipotezlerine İlişkin Etki (Regresyon) Analizleri ve Yorumları

$\mathbf{H}_{1}$ : Veriler neticesinde deneyim alt boyutu toplam varyansin \%8'ini açıklamaktadır. Örgütsel öğrenme kapasitesinin deneyim alt boyutunun iş performansı alt boyutu olan bağlamsal performans üzerine anlamlı bir etkisi bulunmaktadir.

$\mathbf{H}_{2}$ : Veriler neticesinde deneyim alt boyutu toplam varyansin \%7'sini açıklamaktadır. Örgütsel öğrenme kapasitesinin deneyim alt boyutunun iş performansı alt boyutu olan görev performansı üzerine anlamlı bir etkisi bulunmaktadir.

$\mathbf{H}_{3}$ : Veriler neticesinde risk alma alt boyutu toplam varyansın \%7'sini açıklamaktadır. Basit doğrusal regresyon analizi sonucunda Örgütsel öğrenme alt boyutlarından olan risk alma boyutunun bağlamsal performans ile çok zayıf düzeyde ve anlamlı pozitif bir ilişkiye sahip olduğu bulunmuştur. Örgütsel öğrenme kapasitesinin risk alma alt boyutunun iş performansı alt boyutu olan bağlamsal performans üzerine anlamlı bir etkisi bulunmaktadır.

$\mathbf{H}_{4}$ : Veriler neticesinde risk alma alt boyutu toplam varyansin \%6'sinı açıklamaktadır Örgütsel öğrenme kapasitesinin risk alma alt boyutunun iş performans1 alt boyutu olan görev performansı üzerine anlamlı bir etkisi bulunmaktadir.

$\mathbf{H}_{5}$ : Veriler neticesinde diş çevre ile etkileşim alt boyutu toplam varyansın $\% 15$ 'ini açıklamaktadır. Basit doğrusal regresyon analizi sonucunda Örgütsel öğrenme alt boyutlarından olan dış çevre ile etkileşim boyutunun bağlamsal 
performans ile zayıf düzeyde ve anlamlı pozitif bir ilişkiye sahip olduğu bulunmuştur. Örgütsel öğrenme kapasitesinin dış çevre ile etkileşim alt boyutunun iş performansı alt boyutu olan bağlamsal performans üzerine anlamlı bir etkisi bulunmaktadir.

$\mathbf{H}_{6}$ : Veriler neticesinde diş çevre ile etkileşim alt boyutu toplam varyansın $\% 12$ 'sini açıklamaktadır. Örgütsel öğrenme kapasitesinin dıs çevre ile etkileșim alt boyutunun iş performansı alt boyutu olan görev performansı üzerine anlamlı bir etkisi bulunmaktadır.

$\mathbf{H}_{7}$ : Veriler neticesinde diyalog alt boyutu toplam varyansin \%16'sin açıklamaktadır. Basit doğrusal regresyon analizi sonucunda Örgütsel öğrenme alt boyutlarından olan diyalog boyutunun bağlamsal performans ile zayıf düzeyde ve anlamlı pozitif bir ilişkiye sahip olduğu bulunmuștur. Örgütsel öğrenme kapasitesinin diyalog alt boyutunun iş performansı alt boyutu olan bağlamsal performans üzerine anlamlı bir etkisi bulunmaktadır.

$\mathbf{H}_{\mathbf{8}}$ : Veriler neticesinde diyalog alt boyutu toplam varyansin \%15'ini açıklamaktadır. Basit doğrusal regresyon analizi sonucunda Örgütsel öğrenme alt boyutlarından olan diyalog boyutunun görev performansı ile zayıf düzeyde ve anlamlı pozitif bir ilişkiye sahip olduğu bulunmuştur. Örgütsel öğrenme kapasitesinin diyalog alt boyutunun iş performansı alt boyutu olan görev performansı üzerine anlamlı bir etkisi bulunmaktadır.

$\mathbf{H}_{9}$ : Veriler neticesinde katılımc1 karar verme alt boyutu toplam varyansın \%7'sini açıklamaktadır. Basit doğrusal regresyon analizi sonucunda Örgütsel öğrenme alt boyutlarından olan katılımcı karar verme boyutunun bağlamsal performans ile zayıf düzeyde ve anlamlı pozitif bir ilişkiye sahip olduğu bulunmuştur. Örgütsel öğrenme kapasitesinin katılımcı karar alma alt boyutunun iş performansı alt boyutu olan bağlamsal performans üzerine anlamlı bir etkisi bulunmaktadir.

$\mathbf{H}_{\mathbf{1 0}}$ : Veriler neticesinde katılımc karar verme alt boyutu toplam varyansin \%7'sini açıklamaktadır. Basit doğrusal regresyon analizi sonucunda Örgütsel öğrenme alt boyutlarından olan katılımcı karar verme boyutunun görev performans ile zayıf düzeyde ve anlamlı pozitif bir ilişkiye sahip olduğu bulunmuştur. Örgütsel öğrenme kapasitesinin katılımcı karar alma alt boyutunun iş performansı alt boyutu olan görev performansı üzerine anlamlı bir etkisi bulunmaktadır.

$\mathbf{H}_{11}$ : Veriler neticesinde örgütsel öğrenme kapasitesi toplam varyansın \%16'sını açıklamaktadır Örgütsel öğrenme kapasitesinin iş performansı üzerine anlamlı bir etkisi bulunmaktadır. 
DOI: $10.26468 /$ trakyasobed.486447

Tablo 6: Hipotezlerin Sonuçları

\begin{tabular}{|c|c|c|c|c|}
\hline & Hipotezler & B & sig. & Sonuç \\
\hline $\mathrm{H}_{1}$ & $\begin{array}{l}\text { Örgütsel öğrenme kapasitesinin deneyim alt boyutunun iş } \\
\text { performans1 alt boyutu olan bağlamsal performans üzerine } \\
\text { anlamlı bir etkisi bulunmaktadır. }\end{array}$ &, 280 & $\mathrm{P}<, 001$ & Kabul \\
\hline $\mathrm{H}_{2}$ & $\begin{array}{l}\text { Örgütsel öğrenme kapasitesinin deneyim alt boyutunun iş } \\
\text { performansı alt boyutu olan görev performansı üzerine } \\
\text { anlamlı bir etkisi bulunmaktadır. }\end{array}$ & ,267 & $\mathrm{P}<, 001$ & Kabul \\
\hline $\mathrm{H}_{3}$ & $\begin{array}{l}\text { Örgütsel ögrenme kapasitesinin risk alma alt boyutunun iş } \\
\text { performansı alt boyutu olan bağlamsal performans üzerine } \\
\text { anlamlı bir etkisi bulunmaktadır. }\end{array}$ &, 254 & $\mathrm{P}<, 001$ & Kabul \\
\hline $\mathrm{H}_{4}$ & $\begin{array}{l}\text { Örgütsel öğrenme kapasitesinin risk alma alt boyutunun iş } \\
\text { performansı alt boyutu olan görev performansı üzerine } \\
\text { anlamlı bir etkisi bulunmaktadır. }\end{array}$ & ,249 & $\mathrm{P}<, 001$ & Kabul \\
\hline $\mathrm{H}_{5}$ & $\begin{array}{l}\text { Örgütsel öğrenme kapasitesinin dış çevre ile etkileşim alt } \\
\text { boyutunun iş performansı alt boyutu olan bağlamsal } \\
\text { performans üzerine anlamlı bir etkisi bulunmaktadır. }\end{array}$ &, 380 & $\mathrm{P}<, 001$ & Kabul \\
\hline $\mathrm{H}_{6}$ & $\begin{array}{l}\text { Örgütsel öğrenme kapasitesinin dış çevre ile etkileşim alt } \\
\text { boyutunun iş performansı alt boyutu olan görev performans1 } \\
\text { üzerine anlamlı bir etkisi bulunmaktadır. }\end{array}$ & ,349 & $\mathrm{P}<, 001$ & Kabul \\
\hline $\mathrm{H}_{7}$ & $\begin{array}{l}\text { Örgütsel ögrenme kapasitesinin diyalog alt boyutunun iş } \\
\text { performansı alt boyutu olan bağlamsal performans üzerine } \\
\text { anlamlı bir etkisi bulunmaktadır. }\end{array}$ & ,402 & $\mathrm{P}<, 001$ & Kabul \\
\hline $\mathrm{H}_{8}$ & $\begin{array}{l}\text { Örgütsel öğrenme kapasitesinin diyalog alt boyutunun iş } \\
\text { performansı alt boyutu olan görev performansı üzerine } \\
\text { anlamlı bir etkisi bulunmaktadır. }\end{array}$ & ,387 & $\mathrm{P}<, 001$ & Kabul \\
\hline $\mathrm{H}_{9}$ & $\begin{array}{l}\text { Örgütsel öğrenme kapasitesinin katılımcı karar verme alt } \\
\text { boyutunun iş performansı alt boyutu olan bağlamsal } \\
\text { performans üzerine anlamlı bir etkisi bulunmaktadır. }\end{array}$ & ,267 & $\mathrm{P}<, 001$ & Kabul \\
\hline $\mathrm{H}_{10}$ & $\begin{array}{l}\text { Örgütsel öğrenme kapasitesinin katılımc1 karar verme alt } \\
\text { boyutunun iş performansı alt boyutu olan görev performans1 } \\
\text { üzerine anlamlı bir etkisi bulunmaktadır. }\end{array}$ & ,268 & $\mathrm{P}<, 001$ & Kabul \\
\hline $\mathrm{H}_{11}$ & $\begin{array}{l}\text { Örgütsel öğrenme kapasitesinin iş performansı üzerine } \\
\text { anlamlı bir etkisi bulunmaktadır. }\end{array}$ & ,394 & $\mathrm{P}<, 001$ & Kabul \\
\hline
\end{tabular}

Tablo 6' da araştırma sonunda ulaşmış olduğumuz hipotez sonuçlarına yer verilmiştir.

\section{SONUC}

Örgütsel öğrenme kapasitesi ve iş performansı günümüz sağlık işletme yöneticilerinin gündemine girmiş ve hem çalışanlara hem de işletmeye değer katan temel kavramların başında gelmektedir. İnsanlık mevcut olduğu süre boyunca sürekli yeni bilgiler öğrenme, üretme ve sahip olduklarını kullanma yolunda devamlı pozitif yönlü bir döngü içerisinde bulunmaktadır. İşletme yöneticilerinin kendi kurumlarını oluşturan çalışanlarının algılarını önceden bilmesi ve bu 
paralelde çalışanlarını eğitmesi, kanalize etmesi kurum yeteneklerini ve kapasitesini artırma yolunda pozitif katma değer katacağı düşünülmektedir.

Yukarıdaki hipotezlerin toplam varyansları açıklama bağlamında yukarıdan aşağıya sıralamasını yapacak olur isek; \%16 ile örgütsel öğrenme kapasitesinin iş performansına etkisi; sonra yine \%16 ile diyaloğun bağlamsal performansa etkisi, sonra \%15 ile diyaloğun görev performansına etkisi; sonra yine $\% 15$ ile diş çevre ile etkileşimin bağlamsal performansa etkisi; sonra $\% 12$ ile diş çevre ile etkileşimin görev performansına etkisi; sonra $\% 8$ ile deneyimin bağlamsal performansa etkisi; sonra $\% 7$ ile deneyimin görev performansına etkisi, risk almanın bağlamsal performansa etkisi, katılımcı karar vermenin bağlamsal ve görev performansına etkisi; son olarak \%6 ile risk almanın görev performansına etkisi gelmektedir.

Netice itibariyle örgütsel öğrenme kapasitesi işletme bünyesinde çalışanlar tarafindan algılanan iş performansının \%16'sını açıklamakta olduğu yapılan analizler ve bulgular sonucu elde edilmiştir. Yani sadece örgütsel öğrenme kapasitesi ve bunu oluşturan beş alt boyut geliştirilirse diğer bütün şartlar mevcut durumunda kalsa bile işletmenin performansı \%16 artmaktadır. Neticeden fayda görecek olan paydaşlar bu sonucu 2 şekilde ele alabilirler. a) Benim işletmem için $\% 16^{\prime}$ lık bir performans kaybı önemli değil. Başka yerlerden sübvanse ederim. b) İşletmemin performansına etki eden her faktör benim için çok değerlidir. Yapılacak işlemlerin daha ileride belirgin şekilde faydasını görecek olsam dahi, sürdürebilirlik, marka değeri, kalite v.b. açılardan şu anda buna katlanırım.

$\mathrm{Bu}$ araştırmanın verileri 1şığında işletmelerin ikinci yolu seçmeleri önerilmektedir. Nedenlerini siralayacak olursak;

- Öök' nin işletmede yer alması için katlanılacak olan maddi manevi yükümlülüklerin yüksek maliyette olmaması,

- Normal şartlar altında işletme ömürleri dikkate alındığındaki yüksek ve uzun zaman gerekmeyeceğinin düşünülmesi,

- Yapılacak işlemlerde ve verilecek eğitimlerde çalışanlar tarafindan dirençle karşılaşılmayacağının kabullenilmelerin kolay olacağının farz edilmesi,

- Öğrenmenin toplumumuzdaki algısının çok yüksek olması ve bu hassasiyetin pozitif anlamda kullanılabilirliği,

- Ö̈ök için katlanılanların kurum kalitesinde ciddi etkilerinin olacağı,

- Ö̈ök yüksek olan kurumların sürdürülebilir olmalarının kalıcı olacağı,

- İnsan kaynakları açısından tercih sebebi olacağı,

- Çalışanların iş tatminlerinin yüksek olacağı,

- Çalışanların örgütsel vatandaşlık davranışlarının var olacağı,

- Yönetici-çalışan etkileşiminin üst düzeyde olacağ 1 , 
DOI: $10.26468 /$ trakyasobed.486447

- Çalışanların işe tutundurulmalarının ve bağlılıklarının iyi düzeyde olacağı düşünülmektedir.

$\mathrm{Bu}$ araştırmada iş performansına etki için bulunan \%16'lık açıklanabilirlik dışında kalan \%84'lük kısım için ise kısaca özetleyecek olursak şunları söylemek mümkündür:

- Kurum çalışanlarına sağlanan özlük haklarının (aylık kazanç, izin, terfi, ödül, motivasyon, yetki, sorumluluk, sosyal güç ve statü, v.b.) iyi seviyede olmas1,

- Yönetim kademesinin ve en başta bulunan kişinin (hastane müdürü, baştabip, hastane sahibi, genel müdür, ceo v.s.) her anlamda donanımlı olması,

- Kurum marka değerinin yüksek seviyede olması,

- Kurumsal kimliğin ön planda tutulan işletme olması,

- Pazarlamanın iyi yönetiliyor olması,

- Çalışanın işe girmeden önceki kurum hakkındaki pozitif duygulanımları,

- Kurumun insanlar üzerinde geçmişte veya şimdi kötü algılarının olmaması gibi konuları sıralayabiliriz.

Son olarak öneriler bağlamında öök'nin alt boyutları (deneyim, risk alma, dış çevre ile etkileşim, diyalog ve katılımcı karar verme) ekseninde her birine yönelik işletme ne veya neler yaparsa iş performansı hem bağlamsal hem de görev performansı olarak gelişerek büyüyecek sorusuna odaklanacak olursak;

- Deneyim: öök nin ilk alt boyutu olan deneyimi çalışanlara vermek için; usta çırak ilişkisi olarak bilinen kurumda eski ve deneyimli kişileri daha deneyimsiz, kuruma yabanc1, yeni işe alınan, okulu yeni bitirmiş kişilere mihmandar olarak tahsis etmek gerekmektedir. Özellikle sağlik sektöründe devinimin sürekli olduğu yerde, buna her alandan daha çok ihtiyaç vardır. Teknolojik gelişmelerin çok hızlı yaşandığ değişim ve gelişime ayak uyduracak hale getirmek için hizmet içi eğitimlerle veya yerinde tanıtımlarla deneyimlerine destek sağlanacağı düşünülmektedir. Sağlık sektörünün en tepesinde bulunan doktor ve hemşire grubunun bilgi ve yeni olguların sürekli yaşandığı sektörde bu bilgilere ve olgulara ulaşabilmek için kongre, seminer, atölye çalışmaları, sempozyumlar bağlamında destekler sunulması gerekliliği tespit edilmektedir.

- $\quad$ Risk Alma: Erkek çalışanların bu boyutta yüksek oranda olduğu analiz neticesinde varılmıştı. Nedeni olarak yaratılış gereği risk almaya daha uygun yaratılışta oldukları söylenmişti. Diğer kadın çalışanlarında hasta ve çalışan güvenliğinin ön planda tutulduğunu göz önünde bulundurarak cesaretlendirilmelerinin iyi olacağı düşüncesi hâkimdir. Alınacak neticelerin 
katlanılacak riskten daha yüksek olduğu durumlar öne getirilerek yüreklendirilebilirler.

- Dış Çevre ile Etkileşim: Anakütle genelinde kalacak olursak diğer özel hastanelerle ilgili her türlü bilgi, beceri, kabiliyet bağlamında çalışanların etkileşim içinde olacakları ortamlar sunulmalıdır. Diğer kurumlarda meydana gelen negatifpozitif her türlü olaylardan haberdar olmaları sağlanmalıdır.

- Diyalog: İşletme içi bütün servislerle (dâhili branşlar, harici branşlar, ameliyathane, acil, teknik servis v.s.) diyaloga girilebilecek her türlü ortam oluşturulmalı. İşletmeyi oluşturan çalışanların her türlü statü farklarından doğan grupların birbirleriyle olan iletişimlerini artırabilecekleri, kurabilecekleri zeminler tesis edilmeli.

- Katılımeı Karar Verme: Bütün kararlar olmasa da çalışanın ve işletmenin faydasına olacak kararlarda çalışanlarında bu eyleme dâhil edilmeleri elzemdir. Yönetim kademesinin başında bulunan kişinin gözünden bazı şeylerin görülmesi zor olabilmektedir. $\mathrm{Bu}$ nedenle konu hakkında en doğru kararın alınabilmesi için her kademeden kișiye danıșma yerinde olacaktır. Çalışanın motivasyonunu, kuruma bağlılığını, kurum kültürünün oluşmasını ve bunlara bağlı olarak paralelinde performansının artacağı düşünülmektedir.

Yukarıda anlatılan konuları uygulamada kişiden kişiye değişiklik göstermemesi, uzun vadeli hale gelmesi ve sürekli iyileştirilebilir olması gerekliliği dolayisıyla kurum için en uygun sistemin seçilmesi ve sistemden ödün vermeden uygulanması gerekmektedir. Sistemlerin en büyük handikaplarından biri uygulanabilir olmalarıdır. Çalışanların kişisel ve kurumsal tatminleri, huzurlu iş ortamlara sahip olmaları, eşitlik ve adaletin var olduğu kurumlarda, yöneticilerin daha iyi verimler elde ettikleri düşünülmektedir. Araştırmada karşılaşılan kısıtlılıkları ve sınırlılıklar şu şekilde özetlenebilir:

Araştırmada kullanılan araştırma yöntemine göre sınıflandırıldığında, anket araştırmalarıdır. Kapsadıkları süreye göre sınıflandırıldığında, anlık (Crosssectional) araştırmalardandır. Amaçlarına göre sınıflandırıldığında ise literatürel tarama yaparak keşfedici (exploratory) araştırma yapılmış olup daha sonra ise sebep-sonuç (Experimental Designs) araştırma yöntemi kullanarak uygun ölçeklerle ilişki ve etki analizleri yapılmıştır. Araştırmayı kapsam yönünden ele alacak olursak; sadece İstanbul ili Avrupa yakasında hizmet veren özel hastaneleri kapsaması ve 525 kişiye ulaşılmış olması bir sınırlılık olarak düşünüldüğü ifade edilebilir. Katılım sağlayanlar yönünden ele alacak olursak; ankete katılım sağlayanların sorulan soruları anladıkları, gerçekci bir şekilde ele aldıkları, tarafsız bakış açısı ile baktıkları ve cevaplama esnasındaki ruh hallerinin iyi ve sağlıklı oldukları kabul edildiği varsayılmıştır. İlaveten katılımcıların sahip oldukları 
statülerinin, yaşam tarzlarının, edindikleri sosyal rollerin ve demografik faktörlerin cevaplamada bir etkilerinin olmadıkları düşünülmektedir. Birden fazla soru adediyle ölçmeler yapıp bu tarz şüphelerden izale olunması hedeflenmiştir. Araştırma 2017 yılının belirli bir dönemi içerisinde yapılmış olması, daha önceden aynı ana kütlede bu çalışmanın yapılmaması dolayısıyla kıyas yönteminin kullanılamayacak olması da araştırma açısından bir sınırlılık olduğu düşünülmektedir.

\section{KAYNAKÇA}

Aksay, K., Erbil, C., Öğüt, A. (2016) "Çalışanların karar alma sürecine katılımının yenilikçilik kapasitesi ve örgütsel öğrenme üzerine etkisi.” Konya: Selçuk Üniversitesi, İktisadi İdari Bilimler Fakültesi, Sosyal ve Ekonomik Araştırmalar Dergisi. 16 (31), ss. 114-129.

Avcı, N., Küçükusta, D. (2009) "Konaklama İşletmelerinde Örgütsel Öğrenme, Örgütsel Bağlılık ve İşten Ayrılma Eğilimi Arasındaki İlişki.” Ankara: Anatolia Turizm Arastirmalari Dergisi, Cilt 20, Say1 1, ss.33-44,.

Aydoğan, E., Orhan, F., Naldöken, Ü., Beylik, U. ve Aksay, K. (2011) "Sağlık Kurumlarında Örgütsel Öğrenme Kapasitesi: Bir Kamu Hastanesi Örneği." Sivas: C.Ü. Iktisadi ve İdari Bilimler Dergisi, C.12, Say1 2, s.s. 193-213.

Baker, W.E. and Sinkula, J.M. (1999) "The synergistic effect of market orientation and learning orientation on organizational performance." London: Journal of the academy of marketing science,27(4), pp. 411-427.

Cezlan, E.Ç. (2014) "Entelektüel Sermayenin İşletme Yenilikçiliği Ve Işsletme Performansına Etkisi: Să̆lık İşletmelerine Yönelik Bir Uygulama." Yayınlanmamış Doktora Tezi, İstanbul: Beykent Üniversitesi Sosyal Bilimler Enstitüsü.

Chiva, R. and Alegre, J. (2009) "Organizational Learning Capacity and Job Satisfaction: An Emprical Assesment in the Ceramic Tile Industry", London: British Journal Of Management, Vol.20, pp.323-340.

Çelik, V. (2009) "Örgütsel öğrenme kapasitesi ve yeniliğin ve işletme performansına etkisi." Yayınlanmamış Yüksek Lisans Tezi. Kocaeli: Gebze Yüksek Teknoloji Enstitüsü Sosyal Bilimler Enstitüsü.

Efe, M.N. ve Sevinç, H. (2018) "Örgütsel Öğrenme Yeteneklerinin Firma Perfor-

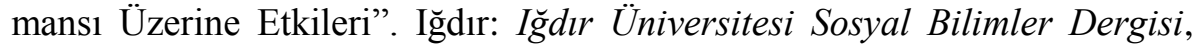
Say1:14, ss. 15.

Erdoğan, A. (2015) Ístatistikî metodlar ve matematik modeller. İstanbul: DER Yayınları. 
Girgin, M. (2015) “Örgütsel öğrenme kapasitesi ile inovasyon eğilimi arasındaki ilişki: bir araştırma." Yayınlanmamış Yüksek Lisans Tezi. Malatya: İnönü Üniversitesi Sosyal Bilimler Enstitüsü.

Goodman, S.A. and Svyantek, D.J. (1999) "Person-Organization Fit and Contextual Performance: Do Shared Values Matter." Journol of vocational Behavior. 55(2), pp. 254-275.

Horuz, İ. (2016) "360 derece performans değerlendirme sisteminin örgütsel ögrenme kapasitesi üzerine etkisi." Yayınlanmamış Yüksek Lisans Tezi. Düzce: Düzce Üniversitesi Sosyal Bilimler Enstitüsü.

Jerez-Gómez, P., Céspedes-Lorente, J. and Valle-Cabrera, R. (2005) "Organizational learning and compensation strategies: evidence from the Spanish chemical industry", Human resource management, 44(3), pp. 279299.

Meydan, C.H. ve Şeşen, H. (2015) Yapısal Eşitlik Modellemesi AMOS Uygulamaları (2. Baskl), Ankara: Detay Yayıncılık.

Smith, C.A., Organ, D.W. and Near, J. P. (1983) "Organizational citizenship behavior: Its nature and antecedents" Journal of Applied Psychology, 68, pp.653-663, USA. 